\title{
Molecular genetics of chronic neutrophilic leukemia, chronic myelomonocytic leukemia and atypical chronic myeloid leukemia
}

\author{
Bing Li ${ }^{1,2}$, Robert Peter Gale ${ }^{3}$ and Zhijian Xiao ${ }^{1,2^{*}}$
}

\begin{abstract}
According to the 2008 World Health Organization classification, chronic neutrophilic leukemia, chronic myelomonocytic leukemia and atypical chronic myeloid leukemia are rare diseases. The remarkable progress in our understanding of the molecular genetics of myeloproliferative neoplasms and myelodysplastic/myeloproliferative neoplasms has made it clear that there are some specific genetic abnormalities in these 3 rare diseases. At the same time, there is considerable overlap among these disorders at the molecular level. The various combinations of genetic abnormalities indicate a multi-step pathogenesis, which likely contributes to the marked clinical heterogeneity of these disorders. This review focuses on the current knowledge and challenges related to the molecular pathogenesis of chronic neutrophilic leukemia, chronic myelomonocytic leukemia and atypical chronic myeloid leukemia and relationships between molecular findings, clinical features and prognosis.
\end{abstract}

Keywords: Molecular genetics, Chronic neutrophilic leukemia, Chronic myelomonocytic leukemia, Atypical chronic myeloid leukemia

\section{Introduction}

Chronic neutrophilic leukemia (CNL), chronic myelomonocytic leukemia (CMML) and atypical chronic myeloid leukemia $(\mathrm{CML})$ are rare diseases categorized into the 2008 World Health Organization (WHO) as either myeloproliferative neoplasms (MPN; CNL) or myelodysplastic/myeloproliferative neoplasms (MDS/ MPN; CMML and a CML). These diseases share several characteristics including an enlarged liver and spleen, an increased WBC and a hyper-cellular bone marrow. They are distinguished from each other based on numbers and types of leukemia cells in the blood, appearance of leukemia cells in the blood and bone marrow cells and cytogenetic and molecular abnormalities including absence of $t(9: 22)$ and BCR/ABL1 and rearrangement of platelet-derived growth factor receptor, alpha polypeptide

\footnotetext{
* Correspondence: zjxiao@medmail.com.cn

'MDS and MPN Centre, Institute of Hematology and Blood Diseases Hospital, Chinese Academy of Medical Sciences \& Peking Union Medical College, 288 Nanjing Road, Tianjin 300020, China

${ }^{2}$ State Key Laboratory of Experimental Hematology, Institute of Hematology and Blood Diseases Hospital, Chinese Academy of Medical Sciences \& Peking Union Medical College, Tianjin, China

Full list of author information is available at the end of the article
}

(PDGFRA), platelet-derived growth factor receptor, beta polypeptide (PDGFRB) or fibroblast growth factor receptor 1 (FGFR1). Previously, it was sometimes difficult to distinguish these disease from each other and from other MPNs including chronic myeloid leukemia (CML), polycythaemia vera (PV), essential thrombocythaemia (ET) and primary myelofibrosis (PMF) which have different molecular abnormalities including mutations in Janus kinase 2 (JAK2), calreticulin (CALR) and MPL protooncogene, thrombopoietin receptor (MPL). Molecular characterization of CNL, CMML and atypical CML has advanced even further with the use of next generation sequencing. Important genetic abnormalities have been identified which help to distinguish between these diseases. This review focuses on the current knowledge and challenges related to the molecular pathogenesis of CNL, CMML and atypical CML and relationships between molecular findings, clinical features and prognosis.

\section{Molecular genetics of CNL Colony stimulating factor 3 receptor (CSF3R) mutations In 2013, Maxson et al. reported frequent mutations in CSF3R in patients with CNL and atypical CML [1]. Such}


mutations are rare in patients with AML. Two types of mutations were found. CSF3R ${ }^{\mathrm{T} 618 \mathrm{I}}$ and $\mathrm{CSF}^{\mathrm{T}} \mathrm{R}^{\mathrm{T} 615 \mathrm{~A}}$ are most common mutations, which are in the membrane proximal region which mediates proliferative and survival signals. These mutations occur alone or with another nonsense mutations truncating the cytoplasmic tail of the coding region important in transduction of maturation and suppression of proliferation [1,2]. Membrane proximal mutations result in activation of JAK signaling pathways and truncation mutations in preferential activation of SRC family-TNK2 kinase signaling (Figure 1A) [1]. The aetiological role of CSF3R ${ }^{\mathrm{T} 618 \mathrm{I}}$ mutation in these diseases was studied in a model in which mice transplanted with $\mathrm{CSF}^{\mathrm{T}} \mathrm{R}^{\mathrm{T} 618 \mathrm{I}}$-expressing hematopoietic cells. These mice developed a CNL-like phenotype characterized by hyper-cellular bone marrow and granulocyte infiltrates in the spleen and liver and died [3].

Pardanani et al. [4] sequenced the implicated exons of CSF3R in 35 suspected subjects with CNL, 12 subjects with confirmed CNL and 6 subjects with CNL and a monoclonal gammopathy or lymphoid neoplasm. All subjects who fulfilled the 2008 WHO criteria for CNL had a CSF3R proximal membrane mutation, most frequently CSF3R $^{\mathrm{T} 618 \mathrm{I}}$. One subject had CSF3R ${ }^{\mathrm{M} 696 \mathrm{~T}}$ and 1, CSF3R ${ }^{\mathrm{I} 598 \mathrm{I}}$. One of these subjects also had a truncating CSF3R mutation. No one with WHO-defined CNL but with a monoclonal gammopathy or lymphoid neoplasm had a CSF3R mutation. These data explain the different bases and prognoses between CNL with and without a monoclonal gammopathy [5-8]. Our study in Chinese with WHO-defined CNL confirmed these findings [9]. We found a CSF3R ${ }^{\mathrm{T} 618 \mathrm{I}}$ mutation in all subjects with CNL without a monoclonal gammopathy but not in 2 subjects with features of CNL with a monoclonal gammopathy. These data indicate CSF3R mutations are a highly sensitive and specific molecular marker for WHOdefined CNL and we suggest it be included into the revised criteria.

\section{JAK2 $2^{\text {V617F }}$}

JAK2 ${ }^{\mathrm{V} 617 \mathrm{~F}}$ is common in patients with BCR/ABL1 negative MPNs and is rare in patients with CML but not in those with lymphoid neoplasms, reactive myeloproliferative disorders or normals [10,11]. About 13 patients with CNL with JAK2 V617F are reported [12-20]. These patients had typical features of CNL without the erythrocytosis, thrombocytosis and bone marrow fibrosis typical of PV, ET and PMF, but CSF3R mutations were not tested. Other recent studies report no JAK2 V617F in patients with CNL with CSF3R mutations [4,9]. Also controversial is whether patients with CNL and JAK2 V617F have a different prognosis than patients with CNL without JAK2 V617F . Some data suggest CNL with JAK2 ${ }^{\text {V617F }}$ mutation has an indolent course with long intervals of stable disease on hydroxyurea [12]. Other data suggest person with $\mathrm{CNL}$ and JAK2 $2^{\mathrm{V} 617 \mathrm{~F}}$ have a worse prognosis and a high risk of transformation to AML $[13,14]$. The underlying issue, of course, is whether the current WHO-criteria are sufficient to accurately diagnose CNL. Do patients with seeming CNL but with JAK2 ${ }^{\mathrm{V} 617 \mathrm{~F}}$ rather than a CSF3R mutation really have $\mathrm{CNL}$ or a different disorder not currently recognized in the WHO-criteria. This distinction is arbitrary but we favor reserving the CNL-designation in future revisions of the WHO-criteria for patients with CSF3R mutations. This would, of course, require a new designator for patients with a clinical phenotype resembling CNL but with JAK $2^{\mathrm{V} 617 \mathrm{~F}}$. This situation is distinct than those in which a person with a CNL phenotype and a CSF3R mutation can also have a $2^{\text {nd }}$ mutation such as SETBP1 (see below).

\section{SET binding protein 1 (SETBP1) mutations}

Three small studies reported SETBP1 mutations in some patients with CNL [4,9,21]. Pardanani et al. [4] reported 6 of 34 patients with clinically-suspected CNL had SETBP1 mutations and 4 of 12 patients with WHOdefined CNL had SETBP1 mutation and CSF3R ${ }^{\mathrm{T} 618 \mathrm{I}}$. We found SETBP1 mutations in 6 of 8 patients with CNL with CSF3R ${ }^{\text {T618I }}$ [9]. Piazza et al. [21] reported a SETBP1 mutation in 4 patients with CNL and a CSF3R mutation. These patients had a worse prognosis than those with CNL without a SETBP1 mutation [4,21,22], an observation requires confirmation.

\section{Molecular genetics of CMML}

Mutations are detected in about 90 percent of patients with CMML [23-25]. These mutations are clustered into four categories: (1) mutations involving epigenetic regulator genes (Figure 1B) [23-26]; (2) mutations involving the spliceosome component pathway (Figure 1C) [27-30]; (3) mutations involving transcription factors [24,31-33]; and (4) mutations involving signaling regulator genes [24,26,34-37].

\section{Epigenetic regulator gene mutations}

Mutations in tet methylcytosine dioxygenase 2 (TET2) mutations are detected in 40-60 percent of patients with CMML [24,26,38,39]. There is controversy whether TET2 mutations in patients with CMML is associated with prognosis. Kosmider et al. [38] reported TET2 mutation was associated with a poor prognosis but this was not confirmed in 2 recent large series [24,30]. Mutations in DNA (cytosine-5-)-methylthransferase 3 alpha (DNMT3A) and isocitrate dehydrogenase 1/2 (IDH1/2) are rare in CMML $[24,26,40]$. DNMT3A mutations trended to occur in CMML-2 and were reported in 6 of 20 patients with CMML-derived AML [26]. Additional sex combs like transcriptional regulator 1 (ASXL1) mutations are detected 


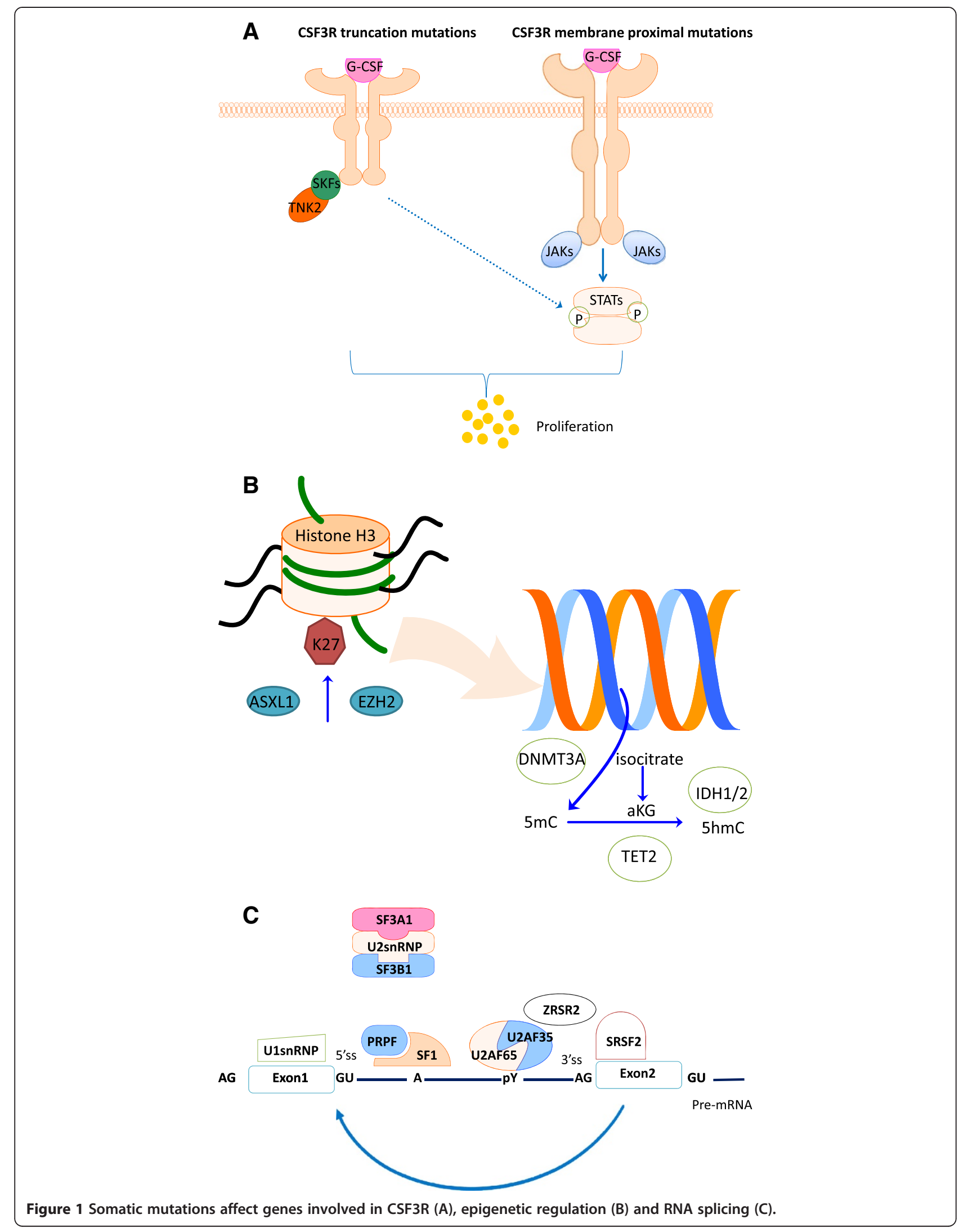


in 40-50 percent of patients with CMML $[24,30,41]$ who are reported to have a higher WBC and higher levels of monocytes and immature myeloid cells in the blood $[24,30]$. Clinical features of patients with CMML and c.1934dupG;p.G646WfsX12 are similar to those of patients with other ASXL1 mutations [24,30]. Conclusions from 2 large series about prognostic impact of ASXL1 mutations on survival are contradictory. Itzykson et al. reported ASXL1 mutation was an unfavorable independent prognostic factor [24]. However, data from Patnaik et al. showed that ASXL1 mutations had no impact on survival [30]. This controversy requires resolution. Enhancer of zeste 2 polycomb repressive complex 2 subunit (EZH2) mutations are uncommon in CMML [24].

\section{Spliceosome component mutations}

About 60 percent of patients with CMML have mutations in genes involved in RNA-splicing [24]. Most common are mutations in serine/arginine-rich splicing factor 2 (SRSF2) in $30-50$ percent of cases. These mutations are associated with increased age, less pronounced anemia and a diploid karyotype but not with prognosis [24,28,29,42]. SRSF2 or zinc finger (CCCH type), RNA-binding motif and serine/ arginine rich 2 (ZRSR2) mutations are frequently concordant with TET2 mutations $[24,28,43]$.

\section{Mutations affecting transcription}

Mutations in the runt-related transcription factor 1 (RUNX1) transcription factor are detected in 15-40 percent of patients with CMML [24,31-33]. Patients with CMML and RUNX1 mutations may have a higher risk of transformation to AML $[31,33]$. CCAAT/enhancer binding protein, alpha (CEBPA) mutations are rare in patients with CMML [33].

\section{Signaling regulator gene mutations}

Kosmider et al. [35] reported variant CSF3R somatic mutations in about 4 percent of patients with CMML with high concordance for ASXL1 mutations. These patients were reported to have a poor prognosis. SETBP1 mutations are detected in about 5 percent of patients with CMML and are associated with a poor prognosis in patients who also have an ASXL1 mutation [35-37]. SETBP1 and CSF3R mutations seem mutually exclusive in CMML. Cbl proto-oncogene, E3 ubiquitin protein ligase (CBL) mutations are detected in about 10 percent of patients with CMML $[24,34,44,45]$.

Recently, Itzykson et al. tracked mutations in single-cellderived myeloid colonies after in vitro culture in patients with CMML [25]. Their data indicate a preferential order of mutation acquisition in progenitor cells. Mutations in TET2 (or IDH1 and IDH2) or ASXL1 occur $1^{\text {st }}$ followed by mutations in SRSF2 or spliceosome component pathway genes followed by mutations in signal transductionrelated genes [25]. These data recall data from studies of the relationship between temporal acquisition of mutations of JAK2 ${ }^{\mathrm{V} 617 \mathrm{~F}}$ and TET2 or ASXL1 in patients with other MPNs where clinical and laboratory features are correlated with which mutation occurs $1^{\text {st }}[46,47]$.

\section{Molecular genetics of atypical CML SETBP1 mutations}

SETBP1 mutations are detected in about $25-30$ percent of patients with atypical CML [21,48]. These patients

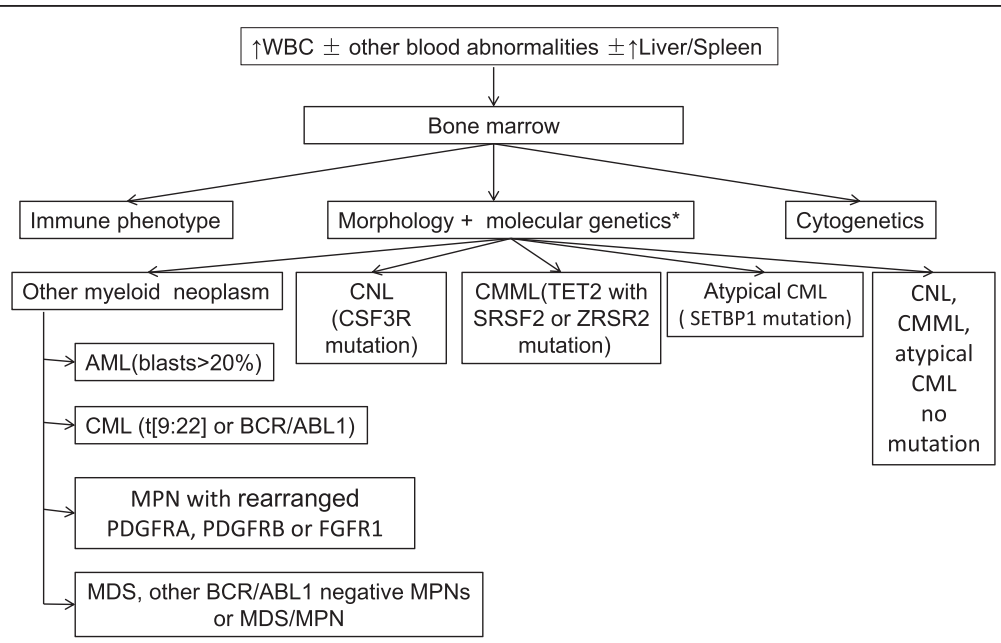

Figure 2 A schematic approach, outlining the evaluation for a patient presenting with peripheral blood leukocytosis. ${ }^{*}$ Molecular genetics test should include mutations involved JAK2, CALR, MPL, CSF3R, TET2, SRSF2, ZRSR2, ASXL1, SETBP1 and BCR-ABL1 fusion genes and rearrangement of PDGFRA, PDGFRB or FGFR1. AML, Acute myeloid leukaemia; CML, chronic myelogenous leukemia; CNL,Chronic neutrophilic leukemia; CMML, chronic myelomonocytic leukemia; MDS, myelodysplastic syndromes; MPN, myeloproliferative neoplasms; MDS/MPN, myelodysplastic/myeloproliferative neoplasms. 
have higher WBCs and a worse prognosis than patients without SETBP1 mutations [21]. SETBP1 mutations are associated with $\operatorname{del}(7)$ and iso(17)(q10)), ASXL1 and CBL mutations are exclusive of JAK2 and TET2 mutations in patients with atypical CML [48]. Recent study [49] showed that overexpression of SETBP1 associated with microRNA desregulation in MPN.

\section{Other mutations}

CSF3R mutations do not occur in patients with atypical CML [4]. In contrast, TET2 mutations are common $[23,37,48,50]$. ASXL1 mutations $[20,51]$ are detected in 20-70 percent of patients with atypical CML and SRSF2 mutations about 40 percent [51]. SRFS2, SETBP1 and ASXL1 mutations are often confounded [51].

\section{Next-generation sequencing (NGS) in MPN and MDS/MPN}

NGS technology, such as whole-exons sequencing (WES) has demonstrated its power in re-sequecing human genomes to enhance our understanding of how molecular genetics affect MPN and MDS/MPN $[1,15,16,21,25]$. However, the challenge is to provide genetic information in a timely and affordable way. Thus, the utility of detailed targeted resequencing by capturing technologies is currently reasonable in clinical practicality. Consequently, molecular biomarkers will soon no longer be sequenced individually. Instead, panels of biomarkers will be assessed in a massively parallel way with high sensitivity and multiplexing in patients with MPN or MDS/MPN for diagnosis and individualized treatment regimens.

\section{Conclusion}

The mutational landscapes or terrains of CNL, CMML and atypical CML are complex, but some mutations are relatively specific in these 3 disorders. Furthermore, the order in which mutations are acquired may correlate with clinical features and prognosis. Therefore, analyse of mutations in MPNs is increasingly important for several reasons. $1^{\text {st }}$, mutation analyses is useful in trying to determine the aetiology of an increased WBC. For example, mutations in CSF3R suggest CNL, SETBP1 mutations, atypical CML and concurrent TET2 and SRSF2 or ZRSR2 mutations, CMML. Analyses of these frequently mutated genes can determine clonality and distinguish neoplasms from non-neoplastic increases in the WBC (Figure 2). $2^{\text {nd }}$, mutations in ASXL1, SEBP1, DNMT3A are associated, albeit inconsistently, with a poor prognosis in MPNs and MDS/MPNs. These data, if confirmed, could be added to prognostic scoring systems. $3^{\text {rd }}$, identifying specific molecular abnormalities can suggest new therapy targets for these diseases, such as hedgehog pathway inhibitors [52].

\section{Competing interests}

RPG is a part-time employee of Celgene Corp., Summit, NJ and scheme. The remaining authors declare no competing financial interests.
Authors' contributions

LB, RPG and XZJ wrote the typescript. All authors read and approved the final manuscript.

\section{Acknowledgements}

Supported in part by National Natural Science Funds (No.81370611, No. 81270585), Tianjin Key Natural Science Funds (12JCZDJC23900), National Public Health Grand Research Foundation (No.201202017) (to ZX). RPG acknowledges support from the NIHR Biomedical Research Centre funding scheme.

\section{Author details}

${ }^{1}$ MDS and MPN Centre, Institute of Hematology and Blood Diseases Hospital, Chinese Academy of Medical Sciences \& Peking Union Medical College, 288 Nanjing Road, Tianjin 300020, China. ${ }^{2}$ State Key Laboratory of Experimental Hematology, Institute of Hematology and Blood Diseases Hospital, Chinese Academy of Medical Sciences \& Peking Union Medical College, Tianjin, China. ${ }^{3}$ Hematology Research Centre, Division of Experimental Medicine, Department of Medicine, Imperial College London, London, UK.

Received: 28 November 2014 Accepted: 4 December 2014 Published online: 12 December 2014

\section{References}

1. Maxson JE, Gotlib J, Pollyea DA, Fleischman AG, Agarwal A, Eide CA Bottomly D, Wilmot B, McWeeney SK, Tognon CE, Pond JB, Collins RH, Goueli B, Oh ST, Deininger MW, Chang BH, Loriaux MM, Druker BJ, Tyner JW: Oncogenic CSF3R mutations in chronic neutrophilic leukemia and atypical CML. N Engl J Med 2013, 368:1781-1790.

2. Dong F, van Buitenen C, Pouwels K, Hoefsloot LH, Lowenberg B, Touw IP: Distinct cytoplasmic regions of the human granulocyte colonystimulating factor receptor involved in induction of proliferation and maturation. Mol Cell Biol 1993, 13:7774-7781.

3. Fleischman AG, Maxson JE, Luty SB, Agarwal A, Royer LR, Abel ML, MacManiman JD, Loriaux MM, Druker BJ, Tyner JW: The CSF3R T618 mutation causes a lethal neutrophilic neoplasia in mice that is responsive to therapeutic JAK inhibition. Blood 2013, 122:3628-3631.

4. Pardanani A, Lasho TL, Laborde RR, Elliott M, Hanson CA, Knudson RA Ketterling RP, Maxson JE, Tyner JW, Tefferi A: CSF3R T618I is a highly prevalent and specific mutation in chronic neutrophilic leukemia. Leukemia 2013, 27:1870-1873.

5. Ito T, Kojima H, Otani K, Komeno T, Mitsuhashi S, Hasegawa Y, Kobayashi T, Ninomiya H, Nagasawa T, Abe T: Chronic neutrophilic leukemia associated with monoclonal gammopathy of undetermined significance. Acta Haematol 1996, 95:140-143.

6. Rovira M, Cervantes F, Nomdedeu B, Rozman C: Chronic neutrophilic leukaemia preceding for seven years the development of multiple myeloma. Acta Haematol 1990, 83:94-95.

7. Kohmura K, Miyakawa Y, Kameyama K, Kizaki M, Ikeda Y: Granulocyte colony stimulating factor-producing multiple myeloma associated with neutrophilia. Leuk Lymphoma 2004, 45:1475-1479.

8. Standen GR, Steers FJ, Jones L: Clonality of chronic neutrophilic leukaemia associated with myeloma: analysis using the X-linked probe M27 beta. J Clin Pathol 1993, 46:297-298.

9. Cui Y, Li B, Gale RP, Jiang Q, Xu Z, Qin T, Zhang P, Zhang Y, Xiao Z: CSF3R, SETBP1 and CALR mutations in chronic neutrophilic leukemia. $J$ Hematol Oncol 2014, 7:77.

10. Levine R, Loriaux M, Huntly BJ, Loh ML, Beran M, Stoffregen E, Berger R, Clark JJ, Willis SG, Nguyen KT, Flores NJ, Estey E, Gattermann N, Armstrong S, Look AT, Griffin JD, Bernard OA, Heinrich MC, Gilliland DG, Druker B, Deininger MW: The JAK2V617F activating mutation occurs in chronic myelomonocytic leukemia and acute myeloid leukemia, but not in acute lymphoblastic leukemia or chronic lymphocytic leukemia. Blood 2005, 106:3377-3379.

11. Pastore F, Schneider S, Christ O, Hiddemann W, Spiekermann K: Impressive thrombocytosis evolving in a patient with a BCR-ABL positive CML in major molecular response during dasatinib treatment unmasks an additional JAK2V617F. Exp Hematol Oncol 2013, 2:24.

12. Ortiz-Cruz K, Amog-Jones G, Salvatore JR: Chronic neutrophilic leukemiawith JAK2 gene mutation. Commun Oncol 2012, 9:127-131. 
13. Mc Lornan DP, Percy MJ, Jones AV, Cross NC, Mc Mullin MF: Chronic neutrophilic leukemia with an associated V617F JAK2 tyrosine kinase mutation. Haematologica 2005, 90:1696-1697.

14. Lee J-H, Ha JS, Ryoo NH, Jeon DS, Kim JR: A case of acute myeloid leukemia transformed from JAK2 V617F-positive chronic neutrophilic leukemia. Lab Med Online 2012, 2:101-104.

15. Klampfl T, Gisslinger $H$, Harutyunyan AS, Nivarthi H, Rumi E, Milosevic JD, Them NC, Berg T, Gisslinger B, Pietra D, Chen D, Vladimer Gl, Bagienski K Milanesi C, Casetti IC, Sant'Antonio E, Ferretti V, Elena C, Schischlik F, Cleary C, Six M, Schalling M, Schonegger A, Bock C, Malcovati L, Pascutto C, SupertiFurga G, Cazzola M, Kralovics R: Somatic mutations of calreticulin in myeloproliferative neoplasms. N Engl J Med 2013, 369:2379-2390.

16. Nangalia J, Massie CE, Baxter EJ, Nice FL, Gundem G, Wedge DC, Avezov E, Li J, Kollmann K, Kent DG, Aziz A, Godfrey AL, Hinton J, Martincorenal I, Van Loo P, Jones AV, Guglielmelli P, Tarpey P, Harding HP, Fitzpatrick JD, Goudie CT, Ortmann CA, Loughran SJ, Raine K, Jones DR, Butler AP, Teague JW, O'Meara S, McLaren S, Bianchi M, et al: Somatic CALR mutations in myeloproliferative neoplasms with nonmutated JAK2. N Engl J Med 2013, 369:2391-2405.

17. Rotunno G, Mannarelli C, Guglielmelli P, Pacilli A, Pancrazzi A, Pieri L, Fanelli T, Bosi A, Vannucchi AM: Associazione Italiana per la Ricerca sul Cancro Gruppo Italiano Malattie Mieloproliferative Investigators. Impact fo calreticulin mutations on clinical and hematological phenotype and outcome in essential thrombocythemia. Blood 2014, 123:1552-1555.

18. Tefferi A, Lasho TL, Finke CM, Finke CM, Knudson RA, Ketterling R, Hanson CH, Maffioli M, Caramazza D, Passamonti F, Pardanani A: CALR vs JAK2 vs MPLmutated or triple-negative myelofibrosis: clinical, cytogenetic and molecular comparisons. Leukemia 2014, 28:1472-1477.

19. Gajendra S, Gupta R, Chandgothia M, Kumar L, Gupta R, Chavan SM: Chronic neutrophilic leukemia with V617F JAK2 mutation. Indian J Hematol Blood Transfus 2014, 30:139-142.

20. Lasho TL, Elliott MA, Pardanani A, Tefferi A: CALR mutation studies in chronic neutrophilic leukemia. Am J Hematol 2014, 89:450.

21. Piazza R, Valletta S, Winkelmann N, Winkelmann N, Redaelli S, Spinelli R, Pirola A, Antolini L, Mologni L, Donadoni C, Papaemmanuil E, Schnittger S, Kim DW, Boultwood J, Rossi F, Gaipa G, De Martini GP, di Celle PF, Jang HG, Fantin V, Bignell GR, Magistroni V, Haferlach T, Pogliani EM, Campbell PJ, Chase AJ, Tapper WJ, Cross NC, Gambacorti-Passerini C: Recurrent SETBP1 mutations in atypical chronic myeloid leukemia. Nat Genet 2013, 45:18-24.

22. Lasho TL, Mims A, Elliott MA, Finke C, Pardanani A, Tefferi A: Chronic neutrophilic leukemia with concurrent CSF3R and SETBP1 mutations: single colony clonality studies, in vitro sensitivity to JAK inhibitors and lack of treatment response to ruxolitinib. Leukemia 2014, 28:1363-1365.

23. Gelsi-Boyer V, Brecqueville M, Devillier R, Murati A, Mozziconacci MJ, Birnbaum D: Mutations in ASXL1 are associated with poor prognosis across the spectrum of malignant myeloid diseases. $J$ Hematol Oncol 2012, 5:12.

24. Itzykson R, Kosmider O, Renneville A, Gelsi-Boyer V, Meggendorfer M Morabito M, Berthon C, Ades L, Fenaux P, Beyne-Rauzy O, Vey N, Braun T, Haferlach T, Dreyfus F, Cross NC, Preudhomme C, Bernard OA, Fontenay M, Vainchenker W, Schnittger S, Birnbaum D, Droin N, Solary E: Prognostic score including gene mutations in chronic myelomonocytic leukemia. J Clin Oncol 2013, 31:2428-2436.

25. Itzykson R, Kosmider O, Renneville A, Morabito M, Preudhomme C, Berthon C, Ades L, Fenaux P, Platzbecker U, Gagey O, Rameau P, Meurice G, Orear C, Delhommeau F, Bernard OA, Fontenay $M$, Vainchenker W, Droin N, Solary E: Clonal architecture of chronic myelomonocytic leukemias. Blood 2013, 121:2186-2198.

26. Jankowska AM, Makishima H, Tiu RV, Szpurka H, Huang Y, Traina F, Visconte V, Sugimoto Y, Prince C, O'Keefe C, His ED, List A, Sekeres MA, Rao A, McDevitt MA, Maciejewski JP: Mutational spectrum analysis of chronic myelomonocytic leukemia includes gene associated with epigenetic regulation: UTX, EZH2, and DNMT3A. Blood 2011, 118:3932-3941.

27. Yoshida K, Sanada M, Shiraishi $Y$, Nowak D, Nagata $Y$, Yamamoto $R$, Sato $Y$, Sato-Otsubo A, Kon A, Nagasaki M, Chalkidis G, Suzuki Y, Shiosaka M, Kawahata R, Yamaguchi T, Otsu M, Obara N, Sakata-Yanagimoto M, Ishiyama K, Mori H, Nolte F, Hofmann WK, Miyawaki S, Sugano S, Haferlach C, Koeffler HP, Shih LY, Haferlach T, Chiba S, Nakauchi H, et al: Frequent pathway mutations of splicing machinery in myelodysplasia. Nature 2011, 478:64-69.
28. Meggendorfer M, Roller A, Haferlach T, Eder C, Dicker F, Grossmann V, Kohlmann A, Alpermann T, Yoshida K, Ogawa S, Koeffler HP, Kern W, Haferlach C, Schnittger S: SRSF2 mutations in 275 cases with chronic myelomonocytic leukemia (CMML). Blood 2012, 120:3080-3088.

29. Kar SA, Jankowska A, Makishima H, Visconte $V$, Jerez A, Sugimotto $Y$, Muramatsu H, Traina F, Afable M, Guinta K, Tiu RV, Przychodzen B, Sakaguchi H, Kojima S, Sekeres MA, List AF, McDevitt MA, Maciejewski JP: Spliceosomal gene mutations are frequent events in the diverse mutational spectrum of chronic myelomonocytic leukemia but largely absent in juvenile myelomonocytic leukemia. Haematologica 2013, 98:107-113.

30. Patnaik MM, Padron E, LaBorde RR, Lasho TL, Finke CM, Hanson CA, Hodnefield JM, Knudson RA, Ketterling RP, Al-kali A, Pardanani A, Ali NA, Komrokji RS, Tefferi A: Mayo prognostic model for WHO-defined chronic myelomonocytic leukemia: ASXL1 and spliceosome component mutations and outcomes. Leukemia 2013, 27:1504-1510.

31. Kuo MC, Liang DC, Huang CF, Shih YS, Wu JH, Lin TL, Shih LY: RUNX1 mutations are frequent in chronic myelomonocytic leukemia and mutations at the C-terminal region might predict acute myeloid leukemia transformation. Leukemia 2009, 23:1426-1431.

32. Gelsi-Boyer V, Trouplin V, Adelaide J, Aceto N, Remy V, Pinson S, Houdayer C, Arnoulet C, Sainty D, Bentires-Alj M, Olschwang S, Vey N Mozziconacci MJ, Birnbaum D, Chaffanet M: Genome profiling of chronic myelomonocytic leukemia: frequent alterations of RAS and RUNX1 genes. BMC Cancer 2008, 8:299.

33. Ernst T, Chase A, Zoi K, Waghorn K, Hidalgo-Curtis C, Score J, Jones A, Grand F, Reiter A, Hochhaus A, Cross NC: Transcription factor mutations in myelodysplastic/myeloproliferative neoplasms. Haematologica 2010, 95:1473-1480

34. Kohlmann A, Grossmann V, Klein H, Schindela S, Weiss T, Kazak B, Dicker F, Schnittger S, Dugas M, Kern W, Haferlach C, Haferlach T: Next-generation sequencing technology reveals a characteristic pattern of molecular mutations in $72.8 \%$ of chronic myelomonocytic leukemia by detecting frequent alterations in TET2, CBL, RAS, and RUNX1. J Clin Oncol 2010, 28:3858-3865

35. Kosmider O, Itzykson R, Chesnais V, Lasho T, Laborde R, Knudson R, Gauthier A, Merlevede J, Ades L, Morabito M, Fontenay M, Tefferi A Droin N, Solary E: Mutations of the colony-stimulating factor-3 receptor gene is a rare event with poor prognosis in chronic myelomonocytic leukemia. Leukemia 2013, 27:1946-1949.

36. Damm F, Itzykson $\mathrm{R}$, Kosmider $\mathrm{O}$, Droin $\mathrm{N}$, Renneville $\mathrm{A}$, Chesnais $\mathrm{V}$ Gelsi-Boyer V, de Botton S, Vey N, Preudhomme C, Clavert A, Delabesse E, Park S, Birnbaum D, Fontenay M, Bernard OA, Solary E: SETBP1 mutations in 658 patients with myelodysplastic syndromes, chronic myelomonocytic leukemia and secondary acute myeloid leukemias. Leukemia 2013, 27:1401-1403.

37. Laborde RR, Patnaik MM, Lasho TL, Finke CM, Hanson CA, Knudson RA, Ketterling RP, Pardanani A, Tefferi A: SETBP1 mutations in 415 patients with primary myelofibrosis or chronic myelomonocytic leukemia: independent prognostic impact in CMML. Leukemia 2013, 27:2100-2102.

38. Kosmider O, Gelsi-Boyer V, Ciudad M, Racoeur C, Jooste V, Vey N, Quesnel B, Fenaux P, Bastie JN, Beyne-Rauzy O, Stamatoulas A, Dreyfus F, Ifrah N, de Botton S, Vainchenker W, Bernard OA, Birnbaum D, Fontenay M, Solary E: Groupe Francophone des Myelodysplasies. TET2 gene mutations is a frequent and adverse event in chronic myelomonocytic leukemia. Haematologica 2009, 94:1676-1681.

39. Tefferi A, Lim KH, Abdel-Wahab O, Lasho TL, Patel J, Patnaik MM, Hanson CA, Pardanani A, Gilliland DG, Levine RL: Detection of mutant TET2 in myeloid malignancies other than myeloproliferative neoplasms: CMML, MDS, MDS/ MPN and AML. Leukemia 2009, 23:1343-1345.

40. Abdel-Wahab O, Pardanani A, Rampal R, Lasho RL, Tefferi A: DNMT3A mutational analysis in primary myelofibrosis, chronic myelomonocytic leukemia and advanced phases of myeloproliferative neoplasms. Leukemia 2011, 25:1219-1220.

41. Gelsi-Boyer V, Trouplin V, Adelaide J, Bonansea J, Cervera N, Carbuccia N, Lagarde A, Prebet T, Nezri M, Sainty D, Olschwang S, Xerri L, Chaffanet M, Mozziconacci MJ, Vey N, Birnbaum D: Mutations of polycomb-associated gene ASXL1 in myelodysplastic syndromes and chronic myelomonocytic leukaemia. Br J Haematol 2009, 145:788-800.

42. Patanaik MM, Lasho TL, Finke CM, Hanson CA, Hodnefield JM, Knudson RA, Ketterling RP, Pardanani A, Tefferi A: Spliceosome mutations involving 
SRSF2, SF3B1, and U2AF35 in chronic myelomonocytic leukemia: prevalence, clinical correlates, and prognostic relevance. Am J Hematol 2013, 88:201-206.

43. Malcovati L, Papaemmanuil E, Ambaglio I, Elena C, Galli A, Della Porta MG, Travaglino E, Pietra D, Pascutto C, Ubezio M, Bono E, Davia MC, Brisci A, Bruno F, Cremonesi L, Ferrari M, Boveri E, Invernizzi R, Campbell PJ, Cazzola M: Driver somatic mutations identify distinct disease entities within myeloid neoplasms with myelodysplasia. Blood 2014

124:1513-1521.

44. Makishima H, Cazzolli H, Szpurka H, Dunbar A, Tiu R, Huh J, Muramatsu H, O'Keefe C, His E, Paquette RL, Kojima S, List AF, Sekeres MA, McDevitt MA, Maciejewski JP: Mutations of e3 ubiquitin ligase cbl family members constitute a novel common pathogenic lesion in myeloid malignancies. J Clin Oncol 2009, 27:6109-6116.

45. Sanada M, Suzuki T, Shih LY, Otsu M, Kato M, Yamazaki S, Tamura A, Honda H, Sakata-Yanagimotto M, Kumano K, Oda H, Yamagata T, Takita J, Gotoh N, Nakazaki K, Kawamata N, Onodera M, Nobuyoshi M, Hayashi Y, Harada H, Kurokawa M, Chiba S, Mori H, Ozawa K, Omine M, Hirai H, Nakauchi H, Koeffler HP, Ogawa S: Gain-of-function of mutated C-CBL tumor suppressor in myeloid neoplasms. Nature 2009, 460:904-908.

46. Beer PA, Delhommeau F, Lecouedic JP, Dawson MA, Chen E, Bareford D, Kusec R, McMullin MF, Harrison CN, Vannucchi AM, Vainchenker W, Green AR: Two routes to leukemic transformation after a JAK2 mutation-positive myeloproliferative neoplasm. Blood 2010, 115:2891-2900.

47. Ferrer-Marin F, Bellosillo B, Martinez-Aviles L, Soler G, Carbonell P, Luengo-Gil G, Caparros E, Torregrosa JM, Besses C, Vicente V: Leukemic transformation driven by an ASXL1 mutation after a JAK2V617F-positive primary myelofibrosis: clonal evolution and hierarchy revealed by next-generation sequencing. J Hematol Oncol 2013, 6:68.

48. Meggendorfer M, Bacher U, Alpermann T, Haferlach C, Kern W, GambacortiPasserini C, Haferlach T, Schnittger S: SETBP1 mutations occur in $9 \%$ of MDS/MPN and in $4 \%$ of MPN cases and are strongly associated with atypical CML, monosomy 7, isochromosome i(17)(q10), ASXL1 and CBL mutations. Leukemia 2013, 27:1852-1860.

49. Albano F, Anelli L, Zagaria A, Coccaro N, Casieri P, Minervini A, Specchia G: SETBP1 and miR-4319 dysregulation in primary myelofibrosis progression to acute myeloid leukemia. J Hematol Oncol 2012, 5:48.

50. Jankowska AM, Szpurka H, Tiu RV, Makishima H, Afable M, Huh J, O'Keefe CL, Ganetzky R, McDevitt MA, Maciejewski JP: Loss of heterozygosity 4q24 and TET2 mutations associated with myelodysplastic/myeloproliferative neoplasms. Blood 2009, 113:6403-6410.

51. Meggendorfer M, Haferlach T, Alpermann T, Jeromin S, Haferlach C, Kern W, Schnittger S: Specific molecular mutation patterns delineate chronic neutrophilic leukemia, atypical chronic myeloid leukemia, and chronic myelomonocytic leukemia. Haematologica 2014, 113159. in press.

52. Tibes R, Mesa RA: Targeting hedgehog signaling in myelofibrosis and other hematologic malignancies. J Hematol Oncol 2014, 7:18.

doi:10.1186/s13045-014-0093-1

Cite this article as: Li et al: Molecular genetics of chronic neutrophilic leukemia, chronic myelomonocytic leukemia and atypical chronic myeloid leukemia. Journal of Hematology \& Oncology 2014 7:93.

\section{Submit your next manuscript to BioMed Central and take full advantage of:}

- Convenient online submission

- Thorough peer review

- No space constraints or color figure charges

- Immediate publication on acceptance

- Inclusion in PubMed, CAS, Scopus and Google Scholar

- Research which is freely available for redistribution 